\title{
Peran IL-1 $\beta$ pada Sepsis dan Gangguan Ginjal Akut Bayi Lahir Prematur
}

Fiva Aprilia Kadi, Tetty Yuniati, Yunia Sribudiani, Dedi Rachmadi

Departemen Ilmu Kesehatan Anak Fakultas Kedokteran Universitas Padjadjaran/ Rumah Sakit Hasan Sadikin, Bandung

Latar belakang. Interleukin- $1 \beta$ berperan dalam kejadian infeksi/inflamasi pada bayi prematur yang dapat menyebabkan gejala klinis berat. Imaturitas organ dapat menyebabkan kejadian inflamasi yang dapat merangsang pembentukan sitokin, salah satunya Interleukin$1 \beta$. Belum ada penelitian yang menghubungkan marker tersebut terhadap sepsis dan gangguan ginjal akut pada bayi prematur.

Tujuan. Melihat peran Interleukin-1 $\beta$ pada kejadian sepsis dan gangguan ginjal akut bayi prematur.

Metode. Studi analitik komparatif kohort pada bayi lahir prematur usia kehamilan $\leq 36$ minggu dan berat lahir $<2000$ gram lahir di RS dr. Hasan Sadikin Bandung. Diperiksakan kadar serum Interleukin-1 $\beta$ usia 24 jam lahir dan serum creatinin usia 24 dan 72 jam. Hasil. Nilai cut-off point Interleukin-1 $\beta$ serum bayi prematur sepsis sebesar 8,67 pg/dL, dengan odd ratio (OR) 6,56 (95\%CI: 2,50 $17,19)$, dan pada bayi prematur dengn gangguan ginjal akut 2,35 pg/dL dengan odd ratio (OR) 7,2 (95\%CI: 4,58-18,20). Keduanya mempunyai nilai sensitifitas dan spesifitas cukup tinggi.

Kesimpulan. Kadar interleukin-1 $\beta$ serum dapat dipertimbangkan menjadi salah satu marker untuk memprediksi kejadian sepsis dan gangguan ginjal akut pada bayi prematur. Sari Pediatri 2020;22(4):208-12

Kata kunci: GgGA, prematur, IL-1 $\beta$

\section{Role of IL-1 $\beta$ in Sepsis and Acute Kidney Injury Premature Infant}

Fiva Aprilia Kadi, Tetty Yuniati, Yunia Sribudiani, Dedi Rachmadi

Background. Interleukin- $1 \beta$ is known to play a very important role in the incidence of prenatal infection/inflammation in preterm infants which can cause severe clinical symptoms. Organ immaturity can cause inflammatory events that can stimulate the formation of cytokines, one of which is interleukin-1 $\beta$. No studies have yet linked these markers to sepsis and acute renal impairment in preterm infants.

Objective. To analyze the role of interleukin- $1 \beta$ in sepsis and acute renal impairment in preterm infants.

Method. A comparative analytical cohort study of preterm infants with gestational age $\leq 36$ weeks and birth weight $<2000$ gram was born at dr. Hasan Sadikin Hospital Bandung. The serum interleukin-1 $\beta$ levels were examined at 24 hours of birth and serum creatinine at 24 and 72 hours.

Results. The cut-off point value of interleukin- $1 \beta$ serum of septic preterm infants was $8.67 \mathrm{pg} / \mathrm{dl}$ with odd ratio 6.56 (95\%CI 2.50 to 17.19 ), while in acute renal impairment it was $2.35 \mathrm{pg} / \mathrm{dl}$ with odd ratio 7,2 (95\%CI 4.58 to 18,.20). Both have high sensitivity and specificity values

Conclusion. Serum Interleukin-1 $\beta$ levels can be considered as a marker to predict sepsis and acute kidney injury in preterm infants. Sari Pediatri 2020;22(4):208-12

Keywords: acute kidney injury, premature, IL-1 $\beta$

Alamat korespondensi: Fiva Aprilia Kadi. Departemen Ilmu Kesehatan Anak, Fakultas Kedokteran, Universitas Padjadjaran, Rumah Sakit Hasan Sadikin Jalan Pasteur no. 38 Bandung 40161, West Java. Email: fiva.kadi@unpad.ac.id 
M

enurut data World Health Organization (WHO) tahun 2017, Indonesia merupakan negara ke-5 terbanyak jumlah kelahiran prematur periode tahun 2016-2017 setelah India, China, Nigeria, dan Pakistan. ${ }^{1}$ Angka kesakitan bayi prematur di kemudian hari masih tinggi, terutama bayi lahir dibawah usia kehamilan 33 minggu, hal ini berkaitan dengan imaturitas organ. ${ }^{2,3}$ Salah satu efek imaturitas terjadi pada organ ginjal, morbiditas pada ginjal masih sedikit diketahui dan perlu diperhatikan. ${ }^{3-6}$ Acute kidney injury (AKI) merupakan gambaran kejadian akut penurunan fungsi ginjal yang dapat berupa kerusakan struktur ginjal dan atau gangguan fungsi. ${ }^{7-9}$ Indonesia menggunakan istilah gangguan ginjal akut (GgGA) untuk menggambarkan kondisi AKI. ${ }^{9}$ Penelitian sebelumnya oleh Stojanovic $\mathrm{dkk}^{5}$ menunjukkan bahwa kejadian GgGA pada neonatal yang dirawat di NICU mencapai 2,4-56\%. Sampai saat ini belum ada ketetapan dalam diagnosis GgGA pada neonatal, salah satu penyebabnya adalah diagnosis GgGA berdasarkan kadar kreatinin. Pada neonatus, kadar kreatinin 48-72 jam pertama masih dipengaruhi oleh ibu, penyebab lainnya adalah salah satu kriteria GgGA adalah oliguri, pada neonatal GgGA lebih banyak non-oliguri karena fungsi tubulus yang masih imatur. ${ }^{10}$ Imaturitas pada tubulus akan menyebabkan reaksi inflamasi dan mengeluarkan sitokin, salah satunya adalah IL-1 $\beta .{ }^{11,12}$

Sepsis neonatorum merupakan penyebab utama morbiditas dan mortalitas pada neonatal. Diagnosis sepsis neonatorum terutama pada neonatal prematur tidak mudah karena onset seringkali tidak jelas dan tidak spesifik. Pada bayi neonatal sepsis jumlah sitokin proinflamatori seperti TNF- $\alpha$, IL-6, IL-1 $\beta$ ditemukan meningkat di serum dan cairan amniotik. ${ }^{13-16}$ Studi sebelumnya menunjukkan peningkatan kadar IL-1 $\beta$ dapat menjadi prediktor beratnya reaksi inflamasi. ${ }^{17-20}$ Peneliti ingin melihat apakah peran IL- $1 \beta$ pada neonatal prematur sepsis dan gangguan ginjal akut (GgGA) bayi prematur yang disebabkan proses inflamasi.

\section{Metode}

Penelitian dilaksanakan bulan Mei sampai Agustus 2018, subyek penelitian adalah neonatal prematur dengan usia kehamilan $\leq 36$ minggu dan berat lahir <2000 gram lahir di RS dr. Hasan Sadikin Bandung.
Penelitian bersifat studi analitik komparatif pendekatan kohort, Dilakukan pemeriksaan kadar serum IL-1 $\beta$ usia 24 jam lahir dan Serum creatinine (SCr) pada usia 24 dan $72 \mathrm{jam}$. Data lain yang dicatat adalah usia kehamilan, berat saat lahir, jenis kelamin, pemeriksaan fisik, laboratorium rutin di usia 24 jam.

Terdapat 112 bayi lahir prematur selama periode penelitian, 80 bayi sesuai kriteria inklusi dan eksklusi. Delapan bayi tidak diikutsertakan karena orangtua menolak ikutserta dalam penelitian ini, total terdapat 72 subyek diikutsertakan penelitian ini. Pemeriksaan IL-1 $\beta$ dengan menggunakan Quantikine ${ }^{\circledast}$ ELISA Human (R\&D Systems, Inc., Minneapolis, USA) rentang standar normal kalibrasi adalah $0.125-8 \mathrm{pg} / \mathrm{mL}$.

Definisi GgGA menurut KDIGO adalah salah satu dari peningkatan kreatinin serum $\geq 0,3 \mathrm{mg} / \mathrm{dl}$ dalam waktu 48 jam; atau peningkatan kreatinin serum $\geq 1,5$ kali nilai dasar, yang diketahui atau dianggap telah terjadi dalam waktu 7 hari sebelumnya; atau volume urine $<0,5 \mathrm{ml} / \mathrm{kg} /$ jam selama 6 jam. ${ }^{21,22}$

Diagnosis sepsis ditegakkan berdasarkan skoring Tolner dengan nilai skor $>10 .{ }^{23}$

\section{Hasil}

Karakteristik umum subjek penelitian

Subyek penelitian 72 bayi prematur usia kehamilan $\leq 36$ minggu yang lahir di RSUP Hasan Sadikin Bandung sejak bulan Juli sampai Agustus 2016. Didapatkan $43 \%$ berjenis kelamin laki-laki dan 57\% perempuan. Rerata berat lahir dari 72 subyek adalah 1505 gram. Pada tabel di atas juga tertera hubungan peningkatan kadar IL-1 $\beta$ terhadap karakteristik subyek. Didapatkan kenaikan serum IL-1 $\beta$ dipengaruhi oleh usia gestasi dan berat lahir.

Pada Tabel 2 ditunjukkan median kadar serum IL-1 $\beta$ bayi prematur sepsis $8,67 \mathrm{pg} / \mathrm{dL}$, sedangkan GgGA 2,35 pg/dL, keduanya secara statistik berbeda bermakna $(\mathrm{p}<0,05)$.

Dari hasil uji beda kadar IL-1 $\beta$ pada bayi prematur sepsis dan prematur GgGA dilakukan perhitungan nilai cut off berdasarkan kurva receiver operating characteristics (ROC), hasilnya tertera pada Gambar 1 dan 2 berikut.

Hasil perhitungan kurva ROC diperoleh nilai cut off kadar IL-1 $\beta$ prematur sepsis adalah $>8,67 \mathrm{pg} / \mathrm{dL}$ dengan sensitifitas $84 \%$ dan spesifisitas $76,6 \%$. 
Tabel 1 Karakteristik subjek penelitian dan kadar serum IL-1 $\quad(n=72)$

\begin{tabular}{|c|c|c|c|c|c|}
\hline \multirow{2}{*}{ Karakteristik } & \multicolumn{3}{|c|}{ Ukuran statistik } & \multicolumn{2}{|c|}{ IL-1 $\beta$} \\
\hline & Rerata (SD) & Median & Rentang & $r_{s}$ & $\mathrm{p}^{*)}$ \\
\hline Jenis kelamin (\%) & & & & 0,126 & 0,291 \\
\hline Laki-laki, 31 (43) & & & & & \\
\hline Perempuan, 41 (57) & & & & & \\
\hline Berat lahir (gram) & $1487,5(262,4)$ & 1505,0 & $850-1900$ & $-0,267$ & 0,023 \\
\hline Usia kehamilan (Minggu) & $31,6(1,1)$ & 32 & $28-36$ & $-0,111$ & 0,042 \\
\hline
\end{tabular}

Keterangan : $r_{s}=$ koefisien korelasi rank Spearman. $\left.{ }^{*}\right)$ Uji Chi-kuadrat

Tabel 2. Korelasi kadar serum IL-1 $\beta$ terhadap kejadian sepsis dan GgGA bayi prematur

\begin{tabular}{|c|c|c|c|c|c|c|}
\hline & \multicolumn{4}{|c|}{ Serum IL-1 $\beta, \mathrm{pg} / \mathrm{Dl}$} & \multirow{2}{*}{ P value* } & \multirow{2}{*}{$\mathrm{r}^{* *}$} \\
\hline & $\mathrm{n}$ & Rerata (SD) & Median & Rentang & & \\
\hline Sepsis & & & & & $<0,001$ & 0,513 \\
\hline $\mathrm{Ya}$ & 25 & $9,88(5,02)$ & 8,67 & $0,87-21,0$ & & \\
\hline Tidak & 47 & $3,86(4,79)$ & 1,4 & $0,38-19,0$ & & \\
\hline AKI & & & & & 0,009 & 0,328 \\
\hline $\mathrm{Ya}$ & 43 & $7,66(5,81)$ & 2,35 & $0,38-21,0$ & & \\
\hline Tidak & 29 & $3,71(4,61)$ & 1,34 & $0,45-15,0$ & & \\
\hline
\end{tabular}

Tabel 3. nilai PPV dan NPV kadar IL-1 $\beta$ serum pada bayi prematur

\begin{tabular}{|c|c|c|c|c|}
\hline & $\mathrm{n}$ & \multicolumn{2}{|c|}{ IL-1 $\beta(\mathrm{pg} / \mathrm{dL})$} & $\mathrm{p}^{*}$ \\
\hline Sepsis & & $<8,67$ & $\geq 8,67$ & \multirow{3}{*}{$<0,001$} \\
\hline Ya & 25 & 5 & 20 & \\
\hline Tidak & 47 & 36 & 11 & \\
\hline GgGA & & $<2,35$ & $\geq 2,35$ & \multirow{3}{*}{0,009} \\
\hline Ya & 43 & 8 & 35 & \\
\hline Tidak & 29 & 15 & 14 & \\
\hline
\end{tabular}

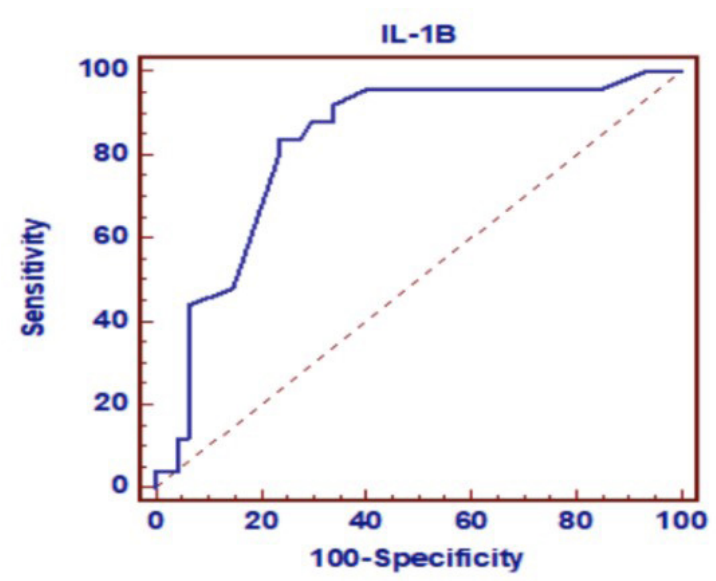

Gambar 1. Kurva ROC kadar IL-1 $\beta$ terhadap prematur sepsis dengan nilai cut-off point $8,67 \mathrm{pg} / \mathrm{dL}$ sensitifitas 84 $\%$ dan spesifisitas 76,6\%, odd ratio (OR) $6.56(95 \% \mathrm{CI}$ $2,50-17,19)$

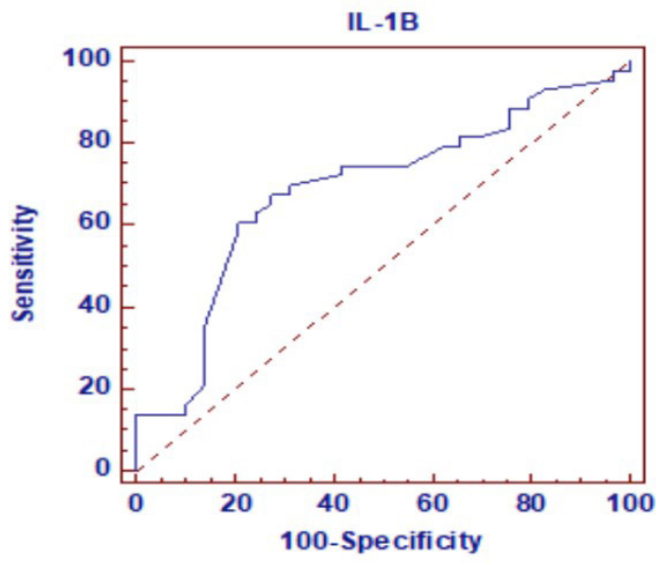

Gambar 2. Kurva ROC kadar IL-1 $\beta$ terhadap prematur GgGA sensitifitas $56 \%$ dan spesifisitas $85 \%$, odd ratio (OR) 7,2 (95\%CI 4,58-18,20) 
Hasil perhitungan kurva ROC diperoleh nilai cut off kadar IL- $1 \beta$ prematur GgGA adalah $>2,35 \mathrm{pg} / \mathrm{dL}$ dengan sensitifitas $56 \%$ dan spesifisitas $85 \%$.

Tabel 3 menghitung nilai prediksi positif (PPV) dan nilai prediksi negatif (NPV) IL-1 $\beta$ terhadap prematur sepsis dan prematur GgGA.

Hasil di atas ditunjukkan PPV kadar IL-1 $\beta$ serum pada prematur sepsis $80 \%$ dan prematur GgGA $81,39 \%$, sedangkan NPV prematur sepsis $76,59 \%$ dan NPV prematur GgGA 51,72\%.

\section{Pembahasan}

Berat lahir dan usia kehamilan secara statistik berkorelasi negatif terhadap kadar serum IL-1 $\beta$, semakin kecil usia kehamilan dan berat lahir, semakin tinggi kadar serum IL-1 $\beta$. Penelitian ini sesuai dengan penelitian yang dilakukan oleh Shalaby ${ }^{24}$ tahun 2018 di Saudi Arabia bahwa semkin kecil usia kehamilan akan berpengaruh terhadap kejadian GgGA dan kemungkinan terjadinya infeksi. Prematuritas berkaitan dengan imaturitas organ dan reaksi inflamasi pada ibu. Reaksi inflamasi pad ibu akan merangsang pembentukan sitokin, salah satunya adalah IL-1 $\beta .{ }^{18,20}$

Aktivasi makrofag dan sel mononuklear terjadi karena adanya reaksi inflamasi pada kelahiran prematur menyebabkan perubahan transkripsi yang berhubungan dengan aktivasi imun. Faktor transkripsi akan meng-aktivasi sitokin proinflamasi seperti TNF- $\alpha$, interferon gamma (IFN- $\gamma$ ), IL-1 $\beta$, IL-6, IL-8, IL-12, dan antiinflamasi seperti IL-10 dan IL-18. ${ }^{18-20,26-}$ ${ }^{28}$ Sitokin TNF- $\alpha$ menjadi mediator reaksi inflamasi akut yang mengatur produksi IL-1 $\beta$. Peningkatan kadar IL-1 $\beta$ dapat menjadi prediktor beratnya reaksi inflamasi. ${ }^{18-20,24-28}$ Sesuai dengan hal tersebut di atas, penelitian ini menunjukkan bahwa kadar serum IL$1 \beta \geq 8,67 \mathrm{pg} / \mathrm{dL}, 64,52 \%$ prematur menjadi sepsis, sedangkan bayi prematur mempunyai kadar serum IL-1 $\beta \geq 2,35 \mathrm{pg} / \mathrm{dL}, 71,43 \%$ akan menjadi GgGA. Penelitian kami sesuai dengan penelitian sebelumnya oleh Girard $\mathrm{dkk}^{18}$ pada bayi neonatal sepsis bahwa jumlah sitokin proinflamatori seperti TNF- $\alpha$, IL-6, IL-1 $\beta$ ditemukan meningkat di serum dan cairan amniotik. Penelitian sebelumnya oleh Otto ${ }^{11}$ pada tahun 2018 menunjukkan adanya perubahan kadar IL-1 $\beta$ serum pada hewan coba yang berkaitan dengan kelainan pada tubulus proksimal ginjal. Hal ini sesuai dengan penelitian kami adanya kenaikan kadar IL-1 $\beta$ pada bayi prematut dengan GgGA, tetapi penelitian kami berbeda dengan hasil penelitian oleh Anders ${ }^{12}$ bahwa kadar IL-1 $\beta$ serum tidak berkaitan langsung dengan GgGA pada hewan coba. Penelitian IL- $1 \beta$ pada bayi prematur belum ada publikasi.

Penelitian ini menggunakan perhitungan dengan kurva ROC. Kurva ROC pada penelitian ini menunjukan bahwa kadar serum IL- $1 \beta \geq 8,67 \mathrm{pg} / \mathrm{dL}$ pada bayi prematur mempunyai risiko 6,56 kali lebih tinggi mengalami sepsis, sedangkan jika prematur mempunyai kadar IL- $1 \beta \geq 2,35 \mathrm{pg} / \mathrm{dL}$ mempunyai risiko 7,2 kali lebih tinggi akan mengalami GgGA. Belum ada penelitian sebelumnya yang menghitung OR IL-1 $\beta$ terhadap kejadian prematur sepsis dan prematur GgGA. Beberapa penelitian menujukkan bahwa bahwa peningkatan sitokin proinflamasi di cairan amniotik dan darah pada neonatal terinfeksi meningkatkan morbiditas di kemudian hari. ${ }^{18,25}$ Salah satu penelitian prospektif melaporkan bahwa sebanyak 26\% terjadi GgGA pada neonatal sepsis. Tingkat kematian lebih tinggi neonatal sepsis dengan cedera ginjal akut jika dibandingkan dengan yang tidak memiliki cedera ginjal akut. Secara klinis, jika neonatal sepsis disertai cedera ginjal akut (CGA) akan memiliki prognosis lebih buruk (tingkat kematian 80\%). ${ }^{14}$

\section{Kesimpulan}

Bayi prematur sepsis dan prematur GgGA mempunyai kadar IL-1 $\beta$ serum lebih tinggi jika dibandingkan dengan bayi prematur tanpa sepsis maupun tanpa GgGa. Masih diperlukan penelitian dengan jumlah sampel lebih banyak dan secara randomized controle trial (RCT) di banyak senter untuk memastikannya.

\section{Daftar pustaka}

1. World Health Organization. WHO recommendations on interventions to improve preterm birth outcomes [document on the internet]. Geneva: The Institute; 2015. Diakses 1 Oktober 2019. Didapat dari: https://apps.who.int/iris/bitstream/ handle/10665/183037/9789241508988_eng.pdf;jsessionid=9C C2706B2CE2BD9B631C46B6B6CCF049? sequence $=1$.

2. Luyckx VA. Preterm Birth and its Impact on Renal Health. Semin Nephrol 2017;37:311-9

3. Stritzke A, Thomas S, Amin H, Fusch C, Lodha A. Renal 
consequences of preterm birth. Molecular and Cellular Pediat 2017;4:2.

4. Viswanathan S, Mhanna MJ. Acute kidney injury in premature infants. J Clin Pediatr Nephrol 2013;20-6.

5. Stojanović V, Barišić N, Milanović B, Doronjski A. Acute kidney injury in preterm infants admitted to a neonatal intensive care unit. Pediatr Nephrol 2014; 29:2213-20.

6. Momtaz HE, Sabzehei MK, Rasuli B, Torabian S. The main etiologies of acute kidney injury in the newborns hospitalized in the neonatal intensive care unit. J Clin Neonatol 2014;3:99-102.

7. Makris K, Spanou L. Acute kidney injury: definition, pathophysiology and clinical phenotypes. Clin Biochem Rev 2016;37:85-98.

8. Ottonello G, Dessì A, Neroni P, Trudu ME, Manus D, Fanos V. Acute kidney injury in neonatal age. J Pediatr Neonatal Individ Med 2014;3:2-5.

9. Noer MS. Soemarso NA. Sabandiyah KH. Prasetyo RV. Rekomendasi gangguan ginjal akut pada anak. Unit Kerja Koordinasi Nefrologi. Jakarta: IDAI; 2014.

10. Durkan N, Alexander T. Acute kidney injury post neonatal asphyxia. J Pediatr 2011;158:e29-33.

11. Otto, G. IL-1 $\beta$ switches on kidney fibrosis. Nat Rev Nephrol 2018;14:475.

12. Anders HJ. Of inflammasomes and alarmins: IL-1 $\beta$ and IL$1 \alpha$ in kidney diseses. J Am Soc Nephrol 2016;27:2564-75.

13. Tam PI, Bendel CM. Diagnotics for neonatal sepsis: current approaches and future directions. Ped Research 2017;82:574-83.

14. Vergnano S, Sharland M, Kazembe P, Mwansambo C, Health P. Neonatal sepsis: an international perspective. Arch Dis Child Fetal Neonatal Ed 2005;90: F220-4.

15. Sankar M, Agarwal R, Deorari A, Paul V. Sepsis in the newborn [document on the Internet]. AIIMS- NICU protocols; 2008. Diakses pada 29 November 2020.Didapat dari: $w w w$. newbornwhocc.org.
16. Haque K. Definitions of bloodstream infection in the newborn. Pediatr Crit Care Med 2005;6:S45-S9.

17. Gomez-Lopez N, StLouis D, Lehr MA, Sanchez-Rodriguez EN, Arenas-Hernandez M. Immune cells in term and preterm labor. Cell Mol Immunol 2014;11: 571-81.

18. Girard S, Tremblay L, Lepage M, sebire G. IL-1 receptor antagonist protects against placental and neurodevelopmental defects induced by maternal inflammation. J Immunol 2010; 184:3997-4005.

19. Simonsen KA, Andersen-Berry A, Delair SF, Davies HD. Early-onset Neonatal Sepsis. Clin Microb Rev 2012;21-47.

20. Haque K. Neonatal sepsis in the very low birth weight preterm infants: part 1: review of patho-physiology. J Med Sci 2010;3:1-10.

21. Saqladi A-WM Al. Acute kidney injury : new definitions and beyond. J Nephrol Ther 2016;61:1-4.

22. Kidney International. Kidney disease improving global outcomes (KDIGO) clinical practice guideline for acute kidney injury [document on the internet]. J Int Soc Nephrol 2012; 21. Diakses pada 29 November 2020. Didapat dari: http:// www.kidney-international.org.

23. Töllner U. Early diagnosis of septicemia in the newborn: clinical studies and sepsis score. Eur J Pediatr 1982;138:331-7.

24. Shalaby,M. Incidence, risk factors, and outcome of neonatal acute kidney injury: a prospective cohort study. Pediatr Nephrol 2018;33:1-8.

25. El Wakeel M, El-Kassas G, Fathy G, dkk. Diagnostic and prognostic values of high sensitive $\mathrm{C}$-reactive protein, tumor nekrosis factor, and Interleukin- $1 \beta$ in Neonatal Sepsis. Australian J of Basic and Applied Sci 2012;6:224-8.

26. Wynn J, Wong H. Pathophysiology and treatment of septic shock in neonates. Clin Perinatol 2010;37:439-79.

27. Gerdes J. Diagnosis and management of bacterial infections in the neonate. Pediatr Clin North Am 2004;51:939-59.

28. Ng P. Diagnostic markers of infection in neonates. Arch Dis Child Fetal Neonatal Ed 2004;89:F229-35. 